Hydrol. Earth Syst. Sci. Discuss.,

https://doi.org/10.5194/hess-2020-55-AC1, 2020

(C) Author(s) 2020. This work is distributed under

the Creative Commons Attribution 4.0 License.

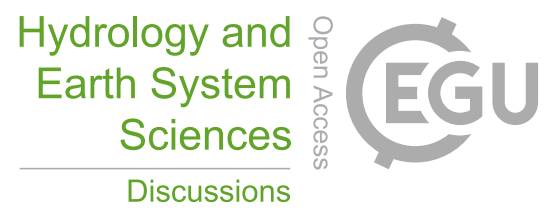

\section{Interactive comment on "Co-incidence Analysis of Changes in Flood Magnitude and Shifts in Flood Timing in a Large Tropical Pluvial River Basin” by Poulomi Ganguli et al.}

\section{Poulomi Ganguli et al.}

pganguli@agfe.iitkgp.ac.in

Received and published: 7 May 2020

The comment was uploaded in the form of a supplement:

https://www.hydrol-earth-syst-sci-discuss.net/hess-2020-55/hess-2020-55-AC1-

supplement.pdf

Interactive comment on Hydrol. Earth Syst. Sci. Discuss., https://doi.org/10.5194/hess-2020-

Printer-friendly version 55, 2020. 